\title{
ANALISIS NILAI TAMBAH BERBAGAI PRODUK OLAHAN INDUSTRI RUMAH TANGGA BERBASIS BAHAN BAKU UBI KAYU DI KECAMATAN GERUNG KABUPATEN LOMBOK BARAT
}

\section{VALUE ADDED ANALYSIS OF VARIOUS PROCESSED PRODUCTS HOUSEHOLD INDUSTRY BASED ON RAW MATERIALS CASSAVA IN GERUNG DISTRICT WEST LOMBOK REGENCY}

\author{
Cici Ria Melani1 ${ }^{*}$, Taslim Sjah², Bambang Dipokusumo ${ }^{2}$ \\ ${ }_{1 *, 2,2}$ Program Studi Agribisnis, Universitas Mataram, Kota Mataram, Indonesia \\ *Email Penulis korespondensi:ciciria99@gmail.com
}

\begin{abstract}
ABSTRAK
Penelitian ini bertujuan untuk: (1) menganalisis besarnya nilai tambah usaha pengolahan berbasis bahan baku ubi kayu di Kecamatan Gerung Kabupaten Lombok Barat, (2) menganalisis besarnya keuntungan usaha pengolahan berbasis bahan baku ubi kayu di Kecamatan Gerung Kabupaten Lombok Barat, dan (3) menganalisis faktor-faktor penghambat usaha pengolahan berbasis bahan baku ubi kayu di Kecamatan Gerung Kabupaten Lombok Barat. Penelitian ini menggunakan metode deskriptif. Jenis data yang digunakan yaitu data kuantitatif dan kualitatif. Sumber data yang digunakan yaitu data primer dan data sekunder. Analisis data menggunakan Metode Hayami dan analisis keuntungan. Hasil penelitian menunjukkan bahwa nilai tambah adalah sebesar Rp. 9.571/kg (dengan rasio sebesar 67,79\% dan tingkat keuntungan sebesar 80,33\%) untuk agroindustri tape ubi kayu, Rp. 18.191/kg (dengan rasio sebesar 71,34\% dan tingkat keuntungan sebesar 88,20\%) untuk agroindustri keripik ubi kayu, dan Rp. $5.558 / \mathrm{kg}$ (dengan rasio sebesar 28\% dan tingkat keuntungan sebesar 64,02\%) untuk agroindustri bubur ubi kayu. Keuntungan sebesar Rp. 384.782/proses produksi dan Rp. 10.389.114/bulan diperoleh dari agroindustri tape ubi kayu, Rp. 741.224/proses produksi dan Rp. 8.894.688/bulan diperoleh dari agroindustri keripik ubi kayu, dan Rp. 53.377/proses produksi dan Rp. 1.281.048/bulan diperoleh dari agroindustri bubur ubi kayu; dan Faktor-faktor penghambat yang dihadapi oleh pengusaha olahan berbasis bahan baku ubi kayu di Kecamatan Gerung Kabupaten Lombok Barat adalah kurangnya ketersediaan bahan baku dan keterbatasan modal usaha.
\end{abstract}

Kata Kunci: Industri Rumah Tangga, Produk Olahan, Nilai Tambah, Keuntungan, Ubi Kayu

\begin{abstract}
This study aims to: (1) analyze the added value of processing business based on cassava raw material in Gerung District, West Lombok Regency, (2) analyze the benefit of processing business based on cassava raw material in Gerung District, West Lombok Regency, and (3) analyze the inhibiting factors of processing business based on cassava raw materials in Gerung District, West Lombok Regency. This research uses a descriptive method. The types of data used are quantitative and qualitative data. Sources of data used are primary data and secondary data. Data analysis using Hayami Method and profit analysis. The results showed that the added value was $R p .9 .571 / \mathrm{kg}$ (with a ratio of $67.79 \%$ and a profit rate of $80.33 \%$ ) for cassava tape agroindustry, Rp. 18,191/kg (with a ratio of $71.34 \%$ and a profit rate of $88.20 \%$ ) for cassava chips agroindustry, and $R p .5 .558 / \mathrm{kg}$ (with a ratio of $28 \%$ and a profit rate of $64.02 \%)$ for cassava pulp agroindustry. Profit of Rp. 384,782/production process and Rp. 10,389,114/month obtained from cassava tape agroindustry, Rp. 741,224/production process and Rp. 8,894,688/month obtained from cassava chips agroindustry, and Rp. 53,377/production process and Rp. 1,281,048/month obtained from cassava pulp agroindustry; and The inhibiting factors faced by processed entrepreneurs based on cassava raw materials in Gerung District, West Lombok Regency are the lack of raw material availability and limited working capital.
\end{abstract}

Keywords: Home Industry, Processed Products, Value Added, Profit, Cassava 


\section{PENDAHULUAN}

Sektor pertanian memiliki keterkaitan yang erat dengan sektor industri. Perkembangan industri yang maju dan kuat didukung oleh pertanian yang tangguh dan sebaliknya, dapat membuat masyarakat Indonesia yang agraris secara bertahap akan mampu menjadi masyarakat agraris yang tangguh sekaligus menjadi masyarakat industri. Sektor pertanian juga dapat menjadi basis dalam mengembangkan kegiatan ekonomi pedesaan melalui pengembangan usaha berbasis pertanian yaitu agribisnis dan agroindustri. Pertumbuhan yang terus positif secara konsisten, sektor pertanian berperan besar dalam menjaga laju pertumbuhan ekonomi nasional (Ismini, 2010).

Mengingat peran pentingnya sektor pertanian bagi pembangunan dan pertumbuhan perekonomian daerah maupun nasional, maka pembangunan sektor ini harus diarahkan kepada pengembangan agroindustri yang dapat menciptakan nilai tambah (added value) produk pertanian sehingga mampu meningkatkan pendapatan petani (Nursan \& Septiadi, 2020). Salah satu komoditas tanaman pangan yang mampu mendukung perkembangan agroindustri adalah ubi kayu. Ubi kayu merupakan salah satu komoditas tanaman pangan yang penting dan sangat strategis karena dapat dimanfaatkan sebagai bahan baku dari berbagai produk olahan suatu industri. Kecamatan Gerung merupakan salah satu kecamatan sebagai penghasil ubi kayu di Kabupaten Lombok Barat. Hasil produksi ubi kayu di Kecamatan Gerung pada tahun 2018 sebesar 120,00 Ton dengan luas tanam 8,00 Ha (BPS Kabupaten Lombok Barat, 2020).

Melimpahnya produksi ubi kayu pada saat panen raya menyebabkan harga ubi kayu di pasar menjadi rendah, sedangkan ubi kayu sendiri memiliki daya simpan yang singkat, mudah rusak, dan membusuk (Rukmana \& Yuniarsih, 2001). Dengan demikian, pengolahan ubi kayu menjadi produk baru merupakan pilihan yang tepat bagi masyarakat di Kecamatan Gerung Kabupaten Lombok Barat. Pengolahan ubi kayu akan meningkatkan keawetan ubi kayu, memperpanjang umur simpan, mengurangi resiko terjadinya kerusakan dan pembusukan, sehingga layak untuk dikonsumsi dan memanfaatkan ubi kayu agar memperoleh nilai jual yang tinggi dipasaran. Sebagai salah satu penghasil ubi kayu di Kabupaten Lombok Barat, Kecamatan Gerung telah menghasilkan berbagai produk olahan berbasis bahan baku ubi kayu diantaranya adalah tape ubi kayu, keripik ubi kayu dan bubur ubi kayu. Adanya kegiatan industri yang mengubah bentuk primer menjadi produk baru yang lebih tinggi nilai ekonomisnya setelah melalui proses pengolahan, maka akan dapat memberikan nilai tambah sehingga terbentuk harga baru yang lebih tinggi dan keuntungan yang lebih besar bila dibandingkan tanpa melalui proses pengolahan. Sjah, et al. (2012), mengemukakan bahwa pada prinsipnya agroindustri ada karena menguntungkan yaitu memberikan tambahan penerimaan yang lebih besar dari pada tambahan biayanya. Selanjutnya, menurut Sjah, et al.,. (2012) pengolahan hasil-hasil pertanian telah terbukti meningkatkan nilai tambah produk.

Penelitian ini bertujuan untuk : (1) menganalisis besarnya nilai tambah usaha pengolahan berbasis bahan baku ubi kayu di Kecamatan Gerung Kabupaten Lombok Barat, (2) menganalisis besarnya keuntungan usaha pengolahan berbasis bahan baku ubi kayu di Kecamatan Gerung Kabupaten Lombok Barat, dan (3) menganalisis faktor-faktor penghambat usaha pengolahan berbasis bahan baku ubi kayu di Kecamatan Gerung Kabupaten Lombok Barat. 


\section{METODE PENELITIAN}

Metode yang digunakan dalam penelitian ini adalah metode deskriptif, yaitu suatu metode yang fokus pada pemecahan masalah aktual yang ada pada masa sekarang. Pemecahan masalah tersebut dilakukan melalui tahapan kegiatan yang meliputi pengumpulan data, menyusun, menganalisis, menginterpretasi data dan membuat kesimpulan. Tujuan dari metode deskriptif adalah untuk membuat deksripsi, gambaran atau lukisan secara sistematis, faktual dan akurat mengenai fakta-fakta, sifat-sifat serta hubungan antar fenomena yang diselidiki (Nazir, 2011). Unit analisis pada penelitian ini adalah pengusaha pengolahan ubi kayu menjadi tape ubi kayu, keripik ubi kayu dan bubur ubi kayu yang ada di Kecamatan Gerung Kabupaten Lombok Barat.

Penelitian ini dilaksanakan di Kecamatan Gerung Kabupaten Lombok Barat. Kecamatan Gerung terdiri dari 3 kelurahan yaitu Gerung Selatan, Gerung Utara dan Dasan Geres serta 11 desa yaitu Banyu Urip, Babussalam, Dasan Tapen, Beleke, Kebunayu, Gapuk, Suka Makmur, Tempos, Mesanggok, Giri Tembesi dan Taman Ayu. Dari ketiga kelurahan dan kesebelas desa tersebut terdapat satu kelurahan yang ditetapkan sebagai lokasi penelitian yaitu Kelurahan Gerung Selatan dengan metode purposive sampling atau sengaja, dengan pertimbangan bahwa di Kelurahan Gerung Selatan terkenal dengan sentra pengolahan ubi kayu khususnya tape ubi kayu. Penentuan jumlah responden dilakukan berdasarkan teknik sampling jenuh. Teknik sampling jenuh menurut Sugiyono (2015) adalah teknik penentuan sampel bila semua anggota populasi sebagai sampel. Hal ini sering dilakukan bila jumlah populasi relatif kecil, kurang dari 30 orang atau penelitian yang ingin membuat generalisasi dengan kesalahan yang sangat kecil. Selanjutnya, menurut Sugiyono (2015) istilah lain sampel jenuh adalah sensus. Dengan demikian, masing-masing responden untuk tape ubi kayu sebanyak 5 pengusaha, keripik ubi kayu sebanyak 11 pengusaha dan bubur ubi kayu sebanyak 1 pengusaha dengan total 17 pengusaha, dengan pertimbangan bahwa hanya terdapat 17 pengusaha pengolahan ubi kayu yang tersebar di lokasi penelitian.

Jenis data dalam penelitian ini meliputi data kuantitatif dan data kualitatif. Sumber data dalam penelitian ini adalah data primer dan data sekunder. Variabel yang diukur untuk menganalisis nilai tambah adalah output, bahan baku, tenaga kerja, harga output, upah rata-rata tenaga kerja, biaya input lain dan nilai output. Adapun variabel yang diukur untuk menganalisis keuntungan adalah biaya produksi meliputi biaya tetap dan biaya variabel, biaya total, bahan baku, bahan penolong, jumlah produk dan harga produk. Selanjutnya, data dikumpulkan melalui wawancara langsung dengan responden menggunakan daftar pertanyaan yang telah dipersiapkan sebelumnya.

Alat analisis data yang digunakan adalah analisis nilai tambah, analisis keuntungan usaha dan analisis deskriptif. Untuk menganalisis besarnya nilai tambah yang diperoleh dihitung menggunakan Metode Hayami. Analisis nilai tambah dengan menggunakan Metode Hayami dapat dilihat pada Tabel 1.

Tabel 1. Analisis Nilai Tambah dengan Menggunakan Metode Hayami

\begin{tabular}{|c|c|c|}
\hline No. & Variabel & Nilai \\
\hline \multicolumn{3}{|c|}{ Output, Input dan Harga } \\
\hline 1. & Output (Kg) & A \\
\hline 2. & Input (Kg) & $\mathrm{B}$ \\
\hline 3. & Tenaga Kerja (HKO) & $\mathrm{C}$ \\
\hline 4. & Faktor Konversi & $\mathrm{D}=\mathrm{A} / \mathrm{B}$ \\
\hline
\end{tabular}




\begin{tabular}{|c|c|c|}
\hline $\begin{array}{l}5 . \\
6 . \\
7 .\end{array}$ & $\begin{array}{l}\text { Koefisien Tenaga Kerja }(\mathrm{HKO} / \mathrm{Kg}) \\
\text { Harga Output }(\mathrm{Rp} / \mathrm{Kg}) \\
\text { Upah Tenaga Kerja }(\mathrm{Rp} / \mathrm{HKO})\end{array}$ & $\begin{array}{l}\mathrm{E}=\mathrm{C} / \mathrm{B} \\
\mathrm{F} \\
\mathrm{G}\end{array}$ \\
\hline \multicolumn{3}{|c|}{ Penerimaan dan Keuntungan } \\
\hline 8. & Harga Bahan Baku (Rp/Kg) & $\mathrm{H}$ \\
\hline 9. & Sumbangan Input Lain (Rp/Kg) & $\mathrm{I}$ \\
\hline 10. & Nilai Output $(\mathrm{Rp} / \mathrm{Kg})$ & $\mathrm{J}=\mathrm{D} \times \mathrm{F}$ \\
\hline 11. & a. Nilai Tambah $(\mathrm{Rp} / \mathrm{Kg})$ & $\mathrm{K}=\mathrm{J}-\mathrm{H}-\mathrm{I}$ \\
\hline & b. Rasio Nilai Tambah (\%) & $\mathrm{L}=(\mathrm{K} / \mathrm{J}) \times 100 \%$ \\
\hline 12. & a. Imbalan Tenaga Kerja $(\mathrm{Rp} / \mathrm{Kg})$ & $\mathrm{M}=\mathrm{E} \times \mathrm{G}$ \\
\hline & b. Rasio Bagian Tenaga Kerja (\%) & $\mathrm{N}=(\mathrm{M} / \mathrm{K}) \times 100 \%$ \\
\hline 13. & $\begin{array}{l}\text { a. Keuntungan }(\mathrm{Rp} / \mathrm{Kg}) \\
\text { b. Tingkat Keuntungan }(\%)\end{array}$ & $\begin{array}{l}O=K-M \\
P=(O / J) \times 100 \%\end{array}$ \\
\hline \multicolumn{3}{|c|}{ Balas Jasa Pemilik Faktor Produksi } \\
\hline 14. & $\begin{array}{l}\text { Marjin Keuntungan }(\mathrm{Rp} / \mathrm{Kg}) \\
\text { a. Pendapatan Tenaga Kerja }(\%) \\
\text { b. Sumbangan Input Lain }(\%) \\
\text { c. Keuntungan Pengusaha }(\%)\end{array}$ & $\begin{array}{l}\mathrm{Q}=\mathrm{J}-\mathrm{H} \\
\mathrm{R}=(\mathrm{M} / \mathrm{Q}) \times 100 \% \\
\mathrm{~S}=(\mathrm{I} / \mathrm{Q}) \times 100 \% \\
\mathrm{~T}=(\mathrm{O} / \mathrm{Q}) \times 100 \%\end{array}$ \\
\hline
\end{tabular}

Sumber: Hayami, et al. (1987)

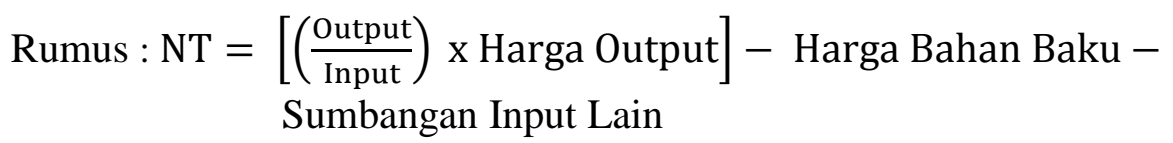

Kriteria Nilai Tambah (NT) adalah :

1) Jika NT $>0$, maka usaha pengolahan ubi kayu memberikan nilai tambah (positif)

2) Jika NT < 0, maka usaha pengolahan ubi kayu tidak memberikan nilai tambah (negatif)

3) Jika NT = 0, maka usaha pengolahan ubi kayu BEP (Break Even Point)

Untuk menganalisis besarnya keuntungan yang diperoleh oleh industri rumah tangga pengolahan ubi kayu, maka data yang dikumpulkan dianalisis menggunakan analisis keuntungan usaha (Abubakar, 2010).

Rumus : $\pi=\mathrm{TR}-\mathrm{TC}$

Keterangan :

$\pi=$ Keuntungan Usaha (Rp)

$\mathrm{TR}=$ Total Penerimaan (Total Revenue)

$\mathrm{TC}=$ Total Biaya $($ Total Cost $)$

Untuk total penerimaan dapat dihitung dengan menggunakan rumus sebagai berikut :

Rumus : $\mathrm{TR}=\mathrm{Q} \times \mathrm{P}$

Keteranagan :

$\mathrm{P}=$ Harga (Price)

$\mathrm{Q}=$ Jumlah Produksi (Quantity)

Untuk total biaya dapat dihitung dengan menggunakan rumus sebagai berikut :

Rumus : $\mathrm{TC}=\mathrm{TFC}+\mathrm{TVC}$

Keterangan :

TFC $=$ Total Biaya Tetap (Total Fixed Cost $)$

TVC $=$ Total Biaya Variabel $($ Total Variable Cost $)$

Kriteria : 
1) Jika TR = TC, maka usaha pengolahan ubi kayu BEP (Break Even Point)

2) Jika TR > TC, maka usaha pengolahan ubi kayu untung

3) Jika TR < TC, maka perusahaan usaha pengolahan ubi kayu rugi

Adapun, untuk menganalisis faktor-faktor penghambat usaha pengolahan ubi kayu digunakan analisis deskriptif, yaitu data yang diperoleh dari responden selanjutnya akan dideskripsikan dan diambil kesimpulan (Nazir, 2011).

\section{HASIL DAN PEMBAHASAN}

\section{Analisis Nilai Tambah}

Analisis nilai tambah digunakan untuk mengetahui besarnya tambahan nilai pada bahan baku ubi kayu yang diolah menjadi tape ubi kayu, keripik ubi kayu dan bubur ubi kayu. Untuk mengetahui besarnya nilai yang ditambahkan pada pengolahan berbasis bahan baku ubi kayu digunakan analisis nilai tambah dengan menggunakan Metode Hayami. Perhitungan tersebut juga memberikan informasi mengenai besarnya pendapatan tenaga kerja langsung dan keuntungan yang diperoleh agroindustri tape ubi kayu, keripik ubi kayu dan bubur ubi kayu dari pengolahan setiap kilogram ubi kayu. Adapun analisis nilai tambah berbagai produk olahan berbasis bahan baku ubi kayu di Kecamatan Gerung dapat dilihat pada Tabel 2.

Tabel 2 Analisis Nilai Tambah Berbagai Produk Olahan Berbasis Bahan Baku Ubi Kayu di Kecamatan Gerung Tahun 2021

\begin{tabular}{|c|c|c|c|c|}
\hline \multirow{2}{*}{\multicolumn{2}{|c|}{$\begin{array}{l}\text { No. } \\
\text { Output, Input dan Harga }\end{array}$}} & \multicolumn{3}{|c|}{ Nilai } \\
\hline & & Tape & Keripik & Bubur \\
\hline 1. & Output (Kg) & 48 & 32,61 & 30 \\
\hline 2. & Input (Kg) & 51 & 45,73 & 15 \\
\hline 3. & Tenaga Kerja (HKO) & 1,65 & 2,2 & 1,93 \\
\hline 4. & Faktor Konversi & 0,94 & 0,71 & 2,00 \\
\hline 5. & Koefisien Tenaga Kerja (HKO/Kg) & 0,03 & 0,05 & 0,13 \\
\hline 6. & Harga Output Rata-rata $(\mathrm{Rp} / \mathrm{Kg})$ & 15.000 & 35.758 & 10.000 \\
\hline 7. & Upah Rata-rata Tenaga Kerja (Rp/HKO) & 58.182 & 44.628 & 15.544 \\
\hline \multicolumn{5}{|c|}{ Penerimaan dan Keuntungan } \\
\hline 8. & Harga Bahan Baku (Rp/Kg) & 3.200 & 3.318 & 4.500 \\
\hline 9. & Sumbangan Input Lain $(\mathrm{Rp} / \mathrm{Kg})$ & 1.347 & 3.990 & 9.942 \\
\hline 10. & Nilai Output (Rp/Kg) & 14.118 & 25.499 & 20.000 \\
\hline & a. Nilai Tambah (Rp/Kg) & 9.571 & 18.191 & 5.558 \\
\hline & b. Rasio Nilai Tambah (\%) & 67,79 & 71,34 & 28 \\
\hline \multirow[t]{2}{*}{12.} & a. Imbalan Tenaga Kerja (Rp/Kg) & 1.882 & 2.147 & 2.000 \\
\hline & b. Rasio Bagian Tenaga Kerja (\%) & 19,67 & 11,80 & 35,98 \\
\hline \multirow[t]{2}{*}{13.} & a. Keuntungan $(\mathrm{Rp} / \mathrm{Kg})$ & 7.688 & 16.044 & 3.558 \\
\hline & b. Tingkat Keuntungan $(\%)$ & 54,46 & 62,92 & 17,79 \\
\hline \multicolumn{5}{|c|}{ Balas Jasa Pemilik Faktor Produksi } \\
\hline \multirow[t]{4}{*}{14.} & Marjin Keuntungan (Rp/Kg) & 10.918 & 22.181 & 15.500 \\
\hline & a. Pendapatan Tenaga Kerja (\%) & 17,24 & 9,68 & 12,90 \\
\hline & b. Sumbangan Input Lain (\%) & 12,34 & 17,99 & 64,14 \\
\hline & c. Keuntungan Pengusaha (\%) & 70,42 & 72,33 & 22,95 \\
\hline
\end{tabular}

Sumber : Data Primer Diolah (2021) 


\section{Nilai Output}

Nilai output merupakan hasil kali antara faktor konversi yaitu perbandingan antara output yang dihasilkan dengan bahan baku (input) yang digunakan dalam satu kali proses produksi dengan harga output. Berdasarkan Tabel 2 diketahui bahwa nilai output agroindustri tape ubi kayu, keripik ubi kayu dan bubur ubi kayu di Kecamatan Gerung Tahun 2021 masing-masing yaitu sebesar Rp. 14.118/kg, Rp. 25.499/kg, dan Rp. 20.000/kg bahan baku. Nilai output ini diperoleh dari hasil kali harga output ratarata masing-masing sebesar Rp. 15.000/kg tape ubi kayu, Rp. 35.758/kg keripik ubi kayu dan Rp. 10.000/kg bubur ubi kayu dengan faktor konversi masing-masing sebesar 0,94 tape ubi kayu, 0,71 keripik ubi kayu dan 2,00 bubur ubi kayu. Faktor konversi tersebut berarti kemampuan ubi kayu menghasilkan tape ubi kayu, keripik ubi kayu dan bubur ubi kayu. Faktor konversi tape ubi kayu sebesar 0,94kg/bahan baku artinya dalam $1 \mathrm{~kg}$ bahan baku ubi kayu yang diolah menghasilkan $0,94 \mathrm{~kg}$ tape ubi kayu atau setiap penambahan $1 \mathrm{~kg}$ bahan baku akan meningkatkan output sebesar $0,94 \mathrm{~kg}$. Faktor konversi keripik ubi kayu sebesar $0,71 \mathrm{~kg} /$ bahan baku artinya dalam 1 $\mathrm{kg}$ bahan baku ubi kayu yang diolah menghasilkan $0,71 \mathrm{~kg}$ keripik ubi kayu atau setiap penambahan $1 \mathrm{~kg}$ bahan baku akan meningkatkan output sebesar $0,71 \mathrm{~kg}$. Faktor konversi bubur ubi kayu sebesar 2,00kg/bahan baku artinya dalam $1 \mathrm{~kg}$ bahan baku ubi kayu yang diolah menghasilkan 2,00 kg bubur ubi kayu atau setiap penambahan $1 \mathrm{~kg}$ bahan baku akan meningkatkan output sebesar 2,00 kg. Dalam hal ini, nilai output akan mempengaruhi besar kecilnya nilai tambah yang diperoleh. Semakin besar nilai output maka nilai tambah dari berbagai produk olahan berbasis bahan baku ubi kayu juga akan semakin tinggi.

\section{Nilai Tambah}

Dari hasil perhitungan nilai tambah pada Tabel 2 diketahui bahwa hasil produksi (output) yang dihasilkan agroindustri tape ubi kayu, keripik ubi kayu dan bubur ubi kayu selama satu kali proses produksi adalah masing-masing sebesar $48 \mathrm{~kg}$, $32,61 \mathrm{~kg}$ dan $30 \mathrm{~kg}$ dengan penggunaan bahan baku (input) masing-masing sebesar 51 $\mathrm{kg}, 45,73 \mathrm{~kg}$ dan $15 \mathrm{~kg}$. Adapun nilai tambah diperoleh dari pengurangan antara nilai produksi (output) dengan harga bahan baku dan sumbangan input lain. Adapun sumbangan input lain diperoleh dari penjumlahan antara biaya transportasi, biaya kebersihan, biaya penyusutan peralatan dan biaya bahan penolong. Sumbangan input lain untuk tape ubi kayu, keripik ubi kayu dan bubur ubi kayu masing-masing sebesar Rp. $1.347 / \mathrm{kg}$, Rp. 3.990/kg dan Rp. $9.942 / \mathrm{kg}$.

Nilai tambah pada pengolahan tape ubi kayu sebesar Rp. $9.571 / \mathrm{kg}$ bahan baku dengan rasio nilai tambah sebesar $67,79 \%$, artinya dengan $1 \mathrm{~kg}$ bahan baku ubi kayu yang digunakan dalam proses produksi dapat memberikan nilai tambah sebesar 67,79\%. Nilai tambah pada pengolahan keripik ubi kayu sebesar Rp. 18.191/kg bahan baku dengan rasio nilai tambah sebesar 71,34\%, artinya dengan $1 \mathrm{~kg}$ bahan baku ubi kayu yang digunakan dalam proses produksi dapat memberikan nilai tambah sebesar $71,34 \%$. Nilai tambah pada pengolahan bubur ubi kayu sebesar Rp. 5.558/kg bahan baku dengan rasio nilai tambah sebesar $28 \%$, artinya dengan $1 \mathrm{~kg}$ bahan baku ubi kayu yang digunakan dalam proses produksi dapat memberikan nilai tambah sebesar $28 \%$. Produk yang memberikan nilai tambah paling tinggi adalah keripik ubi kayu, kemudian tape ubi kayu dan yang paling rendah adalah bubur ubi kayu. Hal ini dikarenakan harga jual ubi kayu yang diolah menjadi keripik ubi kayu lebih tinggi dibandingkan tape ubi kayu dan bubur ubi kayu. Berdasarkan kriteria nilai tambah, 
usaha berbagai produk olahan berbasis bahan baku ubi kayu ini memberikan nilai tambah yang lebih besar dari nol (NT > 0) maka usaha ini positif untuk dijalankan.

\section{Imbalan Tenaga Kerja}

Penggunaan tenaga kerja dalam setiap kegiatan pengolahan tape ubi kayu, keripik ubi kayu dan bubur ubi kayu harus diberikan imbalan, untuk mengetahui besarnya imbalan yang diperoleh tenaga kerja dapat dihitung dari hasil kali koefisien tenaga kerja yaitu perbandingan antara tenaga kerja yang dibutuhkan dengan bahan baku (input) yang digunakan dengan upah rata-rata tenaga kerja. Dari hasil analisis menunjukkan bahwa tenaga kerja pada masing-masing agroindustri ubi kayu sebesar 1,65 HKO untuk tape ubi kayu, 2,2 HKO untuk keripik ubi kayu dan 1,93 HKO untuk bubur ubi kayu dengan penggunaan bahan baku masing-masing sebesar $51 \mathrm{~kg}, 45,73$ $\mathrm{kg}$ dan $15 \mathrm{~kg}$. Adapun koefisien tenaga kerja pada hasil analisis ini adalah 0,03 HKO untuk tape ubi kayu, 0,05 HKO untuk keripik ubi kayu dan 0,13 HKO untuk bubur ubi kayu, artinya dalam setiap satu kilogram bahan baku ubi kayu yang diolah menjadi tape ubi kayu, keripik ubi kayu dan bubur ubi kayu dibutuhkan tenaga kerja masingmasing sebesar 0,03 HKO, 0,05 HKO dan 0,13 HKO.

Upah rata-rata tenaga kerja yang diterima per hari kerja orang adalah total upah yang diterima tenaga kerja dalam satu kali proses produksi dibagi dengan tenaga kerja yang digunakan dalam satu kali proses produksi. Upah rata-rata tenaga kerja pada agroindustri tape ubi kayu, keripik ubi kayu dan bubur ubi kayu masing-masing sebesar Rp. 58.182/HKO, Rp. 44.628/HKO dan Rp. 15.544/HKO. Upah rata- rata tenaga kerja kemudian dikonversikan dengan koefisien tenaga kerja sehingga diperoleh imbalan tenaga kerja untuk setiap satu kilogram bahan baku yang diperoleh dari nilai tambah. Besarnya imbalan tenaga kerja pada agroindustri tape ubi kayu sebesar Rp. 1.882/kg bahan baku dengan rasio bagian tenaga kerja sebesar 19,67\%, kemudian pada agroindustri keripik ubi kayu sebesar Rp. 2.147/kg bahan baku dengan rasio bagian tenaga kerja sebesar $11,80 \%$ dan pada agroindustri bubur ubi kayu sebesar Rp. 2.000/kg bahan baku dengan rasio bagian tenaga kerja sebesar 35,98\%, artinya setiap imbalan tenaga kerja yang diperoleh dari nilai tambah maka bagian tenaga kerja sebesar 19,67\% untuk tape ubi kayu, 11,80\% untuk keripik ubi kayu dan $35,98 \%$ untuk bubur ubi kayu.

\section{Keuntungan}

Setiap kegiatan usaha yang dijalankan untuk menghasilkan produk baru harus menghasilkan keuntungan. Pengolahan ubi kayu menjadi tape ubi kayu, keripik ubi kayu dan bubur ubi kayu merupakan salah satu kegiatan atau usaha yang menghasilkan keuntungan. Keuntungan yang diperoleh menjadi sumber pendapatan untuk setiap pengusaha. Besarnya keuntungan diperoleh dari selisih antara nilai tambah dengan imbalan tenaga kerja. Keuntungan yang diperoleh pengusaha tape ubi kayu sebesar Rp. 7.688/kg bahan baku dengan tingkat keuntungan sebesar 54,46\%. Artinya bahwa setiap $1 \mathrm{~kg}$ ubi kayu yang digunakan untuk memproduksi tape ubi kayu akan menghasilkan keuntungan sebesar 54,46\% dari nilai produksi. Keuntungan yang diperoleh pengusaha keripik ubi kayu sebesar Rp. 16.044/kg bahan baku dengan tingkat keuntungan sebesar $62,92 \%$. Artinya bahwa setiap $1 \mathrm{~kg}$ ubi kayu yang digunakan untuk memproduksi keripik ubi kayu akan menghasilkan keuntungan sebesar $62,92 \%$ dari nilai produksi. Adapun keuntungan yang diperoleh pengusaha bubur ubi kayu sebesar Rp. 3.558/kg bahan baku dengan tingkat keuntungan sebesar $17,79 \%$. Artinya bahwa setiap $1 \mathrm{~kg}$ ubi kayu yang digunakan untuk memproduksi bubur ubi kayu akan menghasilkan keuntungan sebesar 17,79\% dari nilai produksi. 


\section{Balas Jasa Pemilik Faktor Produksi}

Berdasarkan hasil analisis pada Tabel 2 menunjukkan bahwa margin keuntungan merupakan selisih antara nilai produksi (output) dengan harga bahan baku per kilogram. Margin keuntungan ini kemudian didistribusikan untuk pendapatan tenaga kerja, sumbangan input lain dan sebagai keuntungan pengusaha. Margin keuntungan yang diperoleh agroindustri tape ubi kayu, keripik ubi kayu dan bubur ubi kayu masing-masing yaitu sebesar Rp. 10.918/kg, Rp. 22.181/kg dan Rp. 15.500/kg dimana balas jasa yang diterima oleh tenaga kerja masing-masing sebesar 17,24\%, 9,68\% dan 12,90\% artinya setiap Rp. 100,- keuntungan yang diperoleh membutuhkan pengeluaran masing-masing sebesar $17,24 \%, 9,68 \%$ dan 12,90\% untuk diberikan kepada tenaga kerja. Balas jasa untuk sumbangan input lain masing-masing sebesar $12,34 \%, 17,99 \%$ dan 64,14\% artinya setiap Rp. 100,- keuntungan yang diperoleh membutuhkan pengeluaran masing-masing sebesar 12,34\%, 17,99\% dan 64,14\% sebagai biaya input lain. Adapun balas jasa yang diterima oleh pengusaha tape ubi kayu, keripik ubi kayu dan bubur ubi kayu dari kegiatan produksi masing-masing yaitu sebesar 70,42\%, 72,33\% dan 22,95\% artinya, setiap Rp. 100,- keuntungan yang didiperoleh maka akan mendapatkan keuntungan bersih masing-masing sebesar $70,42 \%, 72,33 \%$ dan $22,95 \%$ untuk diberikan kepada pengusaha tape ubi kayu, keripik ubi kayu dan bubur ubi kayu.

\section{Analisis Biaya, Penerimaan dan Keuntungan Industri Rumah Tangga Berbasis Bahan Baku Ubi Kayu di Kecamatan Gerung Analisis Biaya Agroindustri Tape Ubi Kayu, Keripik Ubi Kayu dan Bubur Ubi Kayu di Kecamatan Gerung}

Biaya agroindustri tape ubi kayu, keripik ubi kayu dan bubur ubi kayu terdiri atas biaya tetap dan biaya variabel. Biaya tetap adalah biaya yang tidak berubah walaupun jumlah produksinya berubah yang terdiri atas biaya penyusutan peralatan, biaya transportasi, dan lain sebagainya yang dinyatakan dalam satuan rupiah ( $R p)$. Adapun, biaya variabel adalah biaya yang dikeluarkan selama proses produksi berlangsung yang terdiri atas pembelian bahan baku ubi kayu, bahan penolong, upah tenaga kerja, dan lain sebagainya yang dinyatakan dalam satuan rupiah (Rp). Analisis biaya pada usaha agroindustri tape ubi kayu, keripik ubi kayu dan bubur ubi kayu di Kecamatan Gerung disajikan pada Tabel 3.

Tabel 3 Rata-Rata Biaya Agroindustri Tape Ubi Kayu, Keripik Ubi Kayu dan Bubur Ubi Kayu di Kecamatan Gerung Tahun 2021

\begin{tabular}{llrrr}
\hline \multirow{2}{*}{ No Uraian } & \multicolumn{3}{c}{ Nilai (Rp/PP) } \\
\cline { 3 - 5 } & & Tape Ubi Kayu & $\begin{array}{c}\text { Keripik Ubi } \\
\text { Kayu }\end{array}$ & $\begin{array}{c}\text { Bubur Ubi } \\
\text { Kayu }\end{array}$ \\
\hline 1 & Biaya Variabel & 168.500 & 140636 & 67.500 \\
& a. Biaya Bahan Baku & 59.320 & 175.298 & 146.500 \\
& b. Biaya Bahan Penolong & 96.000 & 98.182 & 30.000 \\
& c. Biaya Tenaga Kerja & 323.820 & 414.116 & 244.000 \\
& Total Biaya Variabel & & & \\
2 & Biaya Tetap & 1.398 & 1.896 & 623 \\
& a. Biaya Penyusutan Alat & 10.000 & 4.400 & 2.000 \\
& b. Biaya Transportasi & & 2.000 & \\
c. Biaya Kebersihan & 11.398 & 8.296 & 2.623
\end{tabular}




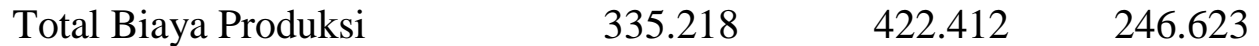 \\ Sumber : Data Primer Diolah (2021) \\ Pada Tabel 3 menunjukkan rata-rata biaya produksi yang dikeluarkan pada agroindustri tape ubi kayu yaitu sebesar Rp. 335.218/PP yang diperoleh dari hasil penjumlahan total biaya variabel sebesar Rp. 323.820/PP dan total biaya tetap sebesar Rp. 11.398/PP. Agroindustri keripik ubi kayu, rata-rata biaya produksi yang dikeluarkan yaitu sebesar Rp. 422.412/PP yang diperoleh dari hasil penjumlahan total biaya variabel sebesar Rp. 414.116/PP dan total biaya tetap sebesar Rp. 8.296/PP. Sedangkan untuk agroindustri bubur ubi kayu, rata-rata biaya produksi yang dikeluarkan yaitu sebesar Rp. 246.623/PP yang diperoleh dari hasil penjumlahan total biaya variabel sebesar Rp. 244.000/PP dan total biaya tetap sebesar Rp. 2.623/PP. Ini berarti, biaya produksi yang dikeluarkan oleh masing-masing agroindustri berbasis bahan baku ubi kayu mulai yang paling tinggi berturut-turut adalah keripik ubi kayu, tape ubi kayu, kemudian bubur ubi kayu. \\ Analisis Penerimaan dan Keuntungan Agroindustri Tape Ubi Kayu, Keripik Ubi Kayu dan Bubur Ubi Kayu di Kecamatan Gerung}

Setiap kegiatan produksi pada agroindustri harus dapat memberikan keuntungan. Keuntungan merupakan selisih dari penerimaan dan pengeluaran dalam proses produksi. Produksi adalah semua kegiatan yang bertujuan untuk menciptakan dan menambahkan keragaman makanan atau barang dan jasa. Sedangkan nilai ouput merupakan pendapatan kotor yang diperoleh dari hasil perkalian jumlah output dan harga ouput. Penerimaan dan keuntungan agroindustri tape ubi kayu, keripik ubi kayu dan bubur ubi kayu di Kecamatan Gerung dapat dilihat pada Tabel 4.

Tabel 4. Rata-Rata Penerimaan dan Keuntungan Agroindustri Tape Ubi Kayu, Keripik Ubi Kayu dan Bubur Ubi Kayu di Kecamatan Gerung Tahun 2021

\begin{tabular}{clrrr}
\hline \multirow{2}{*}{ No } & \multicolumn{1}{c}{ Uraian } & \multicolumn{2}{c}{ Tape Ubi } \\
Kayu & \multicolumn{1}{c}{$\begin{array}{c}\text { Keripik Ubi } \\
\text { Kayu }\end{array}$} & \multicolumn{1}{c}{$\begin{array}{c}\text { Bubur Ubi } \\
\text { Kayu }\end{array}$} \\
\hline 1 & Output (Kg/PP) & 48 & 32,61 & 30 \\
2 & Harga Output (Rp/Kg) & 15.000 & 35.758 & 10.000 \\
3 & Nilai Ouput (Rp/PP) & 720.000 & 1.166 .068 & 300.000 \\
4 & Total Biaya Produksi (Rp/PP) & 335.218 & 422.412 & 246.623 \\
5 & Keuntungan (Rp/PP) & 384.782 & 743.656 & 53.377 \\
6 & Keuntungan (Rp/Bulan) & 10.389 .114 & 8.923 .877 & 1.281 .048 \\
\hline
\end{tabular}

Sumber : Data Primer Diolah (2021)

Berdasarkan Tabel 4 menunjukkan rata-rata keuntungan agroindustri tape ubi kayu yaitu sebesar Rp. 384.782/PP yang diperoleh dari selisih nilai ouput sebesar Rp. 720.000/PP dengan biaya produksi sebesar Rp. 335.218/PP. Agroindustri keripik ubi kayu, rata-rata keuntungan yang didapatkan yaitu sebesar Rp. 743.656/PP yang diperoleh dari selisih nilai ouput sebesar Rp. 1.166.068/PP dengan biaya produksi Rp. 422.412/PP. Sedangkan untuk agroindustri bubur ubi kayu, rata-rata keuntungan yang didapatkan yaitu sebesar Rp. 53.377/PP yang diperoleh dari selisih nilai output sebesar Rp. 300.000/PP dengan biaya produksi Rp. 246.623/PP. Adapun keuntungan tape ubi kayu, keripik ubi kayu dan bubur ubi kayu selama satu bulan yaitu masingmasing sebesar Rp. 10.389.114/bulan, Rp. 8.923.877/bulan dan Rp. 1.281.048/bulan yang diperoleh dari keuntungan selama satu kali proses produksi dikali dengan frekuensi produksi selama satu bulan yaitu masing-masing sebanyak 27 kali untuk 
tape ubi kayu, 12 kali untuk keripik ubi kayu dan 24 kali untuk bubur ubi kayu. Hal ini berarti, keuntungan per proses produksi yang diperoleh oleh masing-masing agroindustri berbasis bahan baku ubi kayu mulai yang paling tinggi berturut-turut adalah keripik ubi kayu, tape ubi kayu, kemudian bubur ubi kayu.

\section{Faktor-Faktor Penghambat Dalam Usaha Pengolahan Berbasis Bahan Baku Ubi Kayu}

Faktor penghambat merupakan keadaan yang dapat menyebabkan pelaksanaan usaha terganggu, terkendala dan tidak dapat terlaksana dengan baik. Faktor penghambat pada usaha berbasis bahan baku ubi kayu di Kecamatan Gerung dapat dilihat pada Tabel 5.

Tabel 5. Faktor Penghambat Usaha Pengolahan Berbasis Bahan Baku Ubi Kayu di Kecamatan Gerung Tahun 2021

\begin{tabular}{cccccccc}
\hline \multirow{2}{*}{ No } & Uraian & \multicolumn{2}{c}{ Tape Ubi Kayu } & \multicolumn{2}{c}{ Keripik Ubi Kayu } & \multicolumn{2}{c}{ Bubur Ubi Kayu } \\
\cline { 2 - 8 } & $\begin{array}{c}\text { Jumlah } \\
\text { (Orang) }\end{array}$ & $\begin{array}{c}\text { Persent } \\
\text { ase }(\%)\end{array}$ & $\begin{array}{l}\text { Jumlah } \\
\text { (Orang) }\end{array}$ & $\begin{array}{c}\text { Persent } \\
\text { ase }(\%)\end{array}$ & $\begin{array}{c}\text { Jumlah } \\
(\text { Orang) }\end{array}$ & $\begin{array}{c}\text { Persent } \\
\text { ase }(\%)\end{array}$ \\
\hline $\begin{array}{l}\text { Kurangnya } \\
1\end{array}$ & 3 & 60 & 6 & 54,55 & 1 & 100 \\
$\begin{array}{l}\text { ketersediaan } \\
\text { bahan baku }\end{array}$ & 3 & 100 & 6 & 54,55 & 0 & 0 \\
\hline $\begin{array}{l}\text { Keterbatasan } \\
\text { modal untuk } \\
\text { pengembangan } \\
\text { usaha }\end{array}$ & 5 & & & & & & \\
\hline
\end{tabular}

Sumber : Data Primer Diolah (2021)

Berdasarkan Tabel 5 menunjukkan bahwa faktor-faktor penghambat dalam usaha pengolahan berbasis bahan baku ubi kayu di Kecamatan Gerung yaitu kurangnya ketersediaan bahan baku dan keterbatasan modal usaha. Hambatan ketersediaan bahan baku dialami oleh 3 orang responden tape ubi kayu dengan persentase sebesar 60\%, 6 responden keripik ubi kayu dengan persentase sebesar $54,55 \%$ dan 1 orang responden bubur ubi kayu dengan persentase $100 \%$. Sedangkan, hambatan keterbatasan modal usaha dialami oleh 5 orang responden tape ubi kayu dengan persentase sebesar $100 \%$ dan 6 responden keripik ubi kayu dengan persentase sebesar $54,55 \%$.

Agroindustri memerlukan bahan baku berupa hasil pertanian yang sesuai untuk diolah menjadi produk baru. Bahan baku ubi kayu yang diproduksi di Kecamatan Gerung akan mempermudah produsen memperolehnya. Disamping lebih dekat dengan sumber bahan baku, harganya bisa lebih murah dibanding membeli bahan baku dari daerah lain yang lokasinya lebih jauh. Kecamatan Gerung sebagai salah satu daerah penghasil ubi kayu tidak dapat mencukupi kebutuhan bahan baku agroindustri baik itu tape ubi kayu, keripik ubi kayu maupun bubur ubi kayu yang ada di Kecamatan Gerung. Hal ini disebabkan oleh meningkatnya permintaan konsumen terhadap produk olahan berbasis bahan baku ubi kayu yang menyebabkan agroindutri tidak tumbuh seiring dengan ketersediaan bahan baku. Dengan demikian pengusaha kerap berlomba-lomba membeli bahan baku ubi kayu. Solusi yang bisa dilakukan oleh pengusaha untuk mengatasi hal ini adalah mengganti bahan baku ubi kayu dengan bahan baku lain. Salah satu bahan baku yang dapat mengganti ubi kayu adalah ubi jalar. Ubi jalar dapat dijadikan sebagai salah satu bahan baku pengganti ubi kayu dalam mengolah produk baik tape, keripik maupun bubur karena sama-sama tergolong 
jenis umbi-umbian. Selain itu, agroindustri berbasis bahan baku ubi kayu tersebut juga tumbuh seiring dengan ketersediaan bahan baku ubi jalar yang relatif mencukupi untuk memenuhi permintaan konsumen di Kecamatan Gerung.

Faktor penghambat yang kedua yaitu keterbatasan modal untuk pengembangan usaha. Modal usaha adalah sesuatu yang digunakan untuk mendirikan atau menjalankan suatu usaha. Secara umum hambatan yang dihadapi dalam menjalankan usaha berbasis bahan baku ubi kayu adalah masalah keterbatasan modal usaha. Ratarata responden kesulitan untuk memenuhi permintaan konsumen yang sewaktu-waktu meningkat karena tidak memiliki modal yang cukup untuk memproduksi tape ubi kayu dan keripik ubi kayu dalam jumlah yang lebih besar. Hal inilah yang menyebabkan jumlah dan frekuensi produksi baik tape ubi kayu maupun keripik ubi kayu dari waktu ke waktu tidak pernah mengalami peningkatan produksi. Hasil ini sesuai dengan penelitian Utama FR \& Nursan (2020) yang menemukan bahwa faktor modal merupakan hambatan dalam penerapan pertanian. Untuk mengatasi masalah tersebut beberapa responden memberlakukan sistem uang muka atau down payment (DP) bagi para konsumen yang hendak membeli tape ubi kayu dan keripik ubi kayu dalam jumlah yang relatif besar. Dengan demikian, produsen dapat memenuhi permintaan tape ubi kayu dan keripik ubi kayu dengan uang muka yang diberikan konsumen. Namun tidak sedikit konsumen yang mau menerapkan sistem ini, sehingga modal usaha masih menjadi hambatan bagi para produsen agroindustri berbasis bahan baku ubi kayu. Dengan demikian, solusi yang bisa dilakukan oleh pengusaha untuk mengatasi hal ini adalah dengan cara melakukan mitra dengan lembaga ekonomi keuangan seperti bank dan koperasi, agar mempermudah dalam medapatkan modal untuk pengembagan usahanya. Selain itu, pengusaha dapat mengajukan bantuan usaha kepada pemerintah. Salah satu program bantuan yang ditawarkan pemerintah adalah Bantuan Langsung Tunai (BLT) dari Kementerian Koperasi dan Usaha Kecil dan Menengah (Kemenkop). Bantuan Langsung Tunai atau Banpres Produktif merupakan bantuan yang diberikan pada para pelaku Usaha Mikro Kecil dan Menengah (UMKM) di Indonesia. Dengan adanya solusi tersebut pengusaha dapat mengatasi hambatan dalam hal keterbatasan modal untuk pengembangan usaha, sehingga dapat meningkatkan jumlah produksi untuk memenuhi permintaan konsumen di Kecamatan Gerung.

\section{KESIMPULAN DAN SARAN}

\section{Kesimpulan}

Berdasarkan hasil penelitian dan pembahasan, maka dapat ditarik kesimpulan sebagai berikut :

1. Nilai tambah adalah sebesar Rp. 9.571/kg (dengan rasio sebesar 67,79\% dan tingkat keuntungan sebesar 80,33\%) untuk agroindustri tape ubi kayu, Rp. $18.191 / \mathrm{kg}$ (dengan rasio sebesar 71,34\% dan tingkat keuntungan sebesar 88,20\%) untuk agroindustri keripik ubi kayu, dan Rp. 5.558/kg (dengan rasio sebesar 28\% dan tingkat keuntungan sebesar 64,02\%) untuk agroindustri bubur ubi kayu.

2. Keuntungan adalah sebesar Rp. 384.782/proses produksi (Rp. 10.389.114/bulan) dari agroindustri tape ubi kayu, Rp. 741.224/proses produksi (Rp. 8.894.688/bulan) dari agroindustri keripik ubi kayu, dan Rp. 53.377/proses produksi (Rp. 1.281.048/bulan) dari agroindustri bubur ubi kayu. 
3. Faktor-faktor penghambat yang dihadapi oleh pengusaha olahan berbasis bahan baku ubi kayu di Kecamatan Gerung Kabupaten Lombok Barat adalah kurangnya ketersediaan bahan baku dan keterbatasan modal untuk pengembangan usaha.

\section{Saran}

Berdasarkan hasil penelitian yang dilaksanakan pada produk berbasis bahan baku ubi kayu di Kecamatan Gerung, maka dapat disarankan bahwa :

1. Bagi pengusaha pengolahan ubi kayu diharapkan untuk terus mempertahankan, mengembangkan dan meningkatkan produktivitas usaha yang dijalankan karena usaha pengolahan ubi kayu telah memberikan nilai tambah dan keuntungan yang cukup tinggi.

2. Bagi pengusaha pengolahan ubi kayu diharapkan untuk melakukan mitra dengan lembaga ekonomi keuangan seperti bank dan koperasi dan mencari informasi mengenai berbagai program bantuan yang diberikan pemerintah kepada para pelaku Usaha Mikro, Kecil dan Menengah (UMKM) agar mempermudah dalam medapatkan modal untuk pengembagan usaha.

3. Bagi pengusaha sangat penting mencari informasi pasar, mulai dari pesaing, kendala, hingga tingkat kebutuhan produk baik tape ubi kayu, kripik ubi kayu dan bubur ubi kayu sehingga dapat menyusun strategi yang lebih baik guna mendapat keuntungan yang tinggi.

\section{DAFTAR PUSTAKA}

Abubakar. (2010). Agribisnis Teori dan Aplikasi. Jakarta: Gaung Persada Press.

BPS Lombok Barat. (2020). Kecamatan Gerung dalam Angka 2020. Kabupaten Lombok Barat: Badan Pusat Statistik Kabupaten Lombok Barat.

Hayami Y., Kawagoe, T., Morooka, Y \& Siregar, M. (1987). Agricultural Marketing and Processing in Upland Java A Perspective From A Sunda Village. Bogor: CGPRT Centre.

Ismini. (2010). Analisis Nilai Tambah dan Strategi Pemasaran Keripik Singkong di Perusahaan Mickey Mouse di Malang. Jurnal Agrika, 4 (2), 119-129.

Nazir, M. (2011). Metode Penelitian. Jakarta: Ghalia Indonesia.

Nursan, M., \& Septiadi, D. (2020). Penentuan Prioritas Komoditas Unggulan Peternakan di Kabupaten Sumbawa Barat. Jurnal Agribisnis Dan Ilmu Sosial Ekonomi Pertanian, 5(1), 29-34.

Rukmana, R., \& Y. Yuniarsih. (2001). Aneka Olahan Ubi kayu. Yogyakarta: Kanisius. Sjah T, Rosmilawati, \& Zainuri. (2012). Rencana Bisnis Untuk Pengusaha Kecil dan Pemula dalam Usaha Pengolahan Hasil Pertanian. Mataram: Mataram University Press.

Sugiyono. (2015). Metode Penelitian Kuantitatif. Kualitatif dan R\&D. Bandung: Alfabeta.

Utama FR, A. F., \& Nursan, M. (2020). Analisis Respon dan Faktor-Faktor yang Mempengaruhi Petani terhadap Penerapan Pertanian Organik di Kota Mataram. JIA (Jurnal Ilmiah Agribisnis) : Jurnal Agribisnis Dan Ilmu Sosial Ekonomi Pertanian, 5(3), 93-103. https://doi.org/10.37149/jia.v5i3.12140 